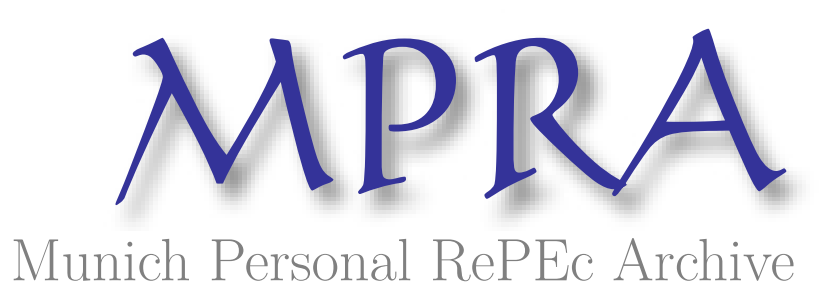

\title{
The Regional Benefits of the Employer of Last Resort Program
}

Murray, Michael/ M J

Bemidji State University

12 January 2012

Online at https://mpra.ub.uni-muenchen.de/35981/

MPRA Paper No. 35981, posted 17 Jan 2012 07:03 UTC 


\title{
The Regional Benefits of the Employer of Last Resort Program
}

\author{
Michael J. Murray, Ph.D. \\ Department of Economics \\ Bemidji State University \\ mmurray@bemidjistate.edu
}

January 15, 2012

\begin{abstract}
The Employer of Last Resort (ELR) program is a New Deal type of program to provide a government position for anyone seeking work. Unlike private industries who compete over prices and wages, the ELR "industry" is not meant to compete with the private sector; rather it provides public services that are not bought by the private sector. The task here is to estimate the private sector effects of the implementation of the ELR program for the State of Missouri.
\end{abstract}

JEL Codes: B51, C3, E11, E12, E23, E24 


\section{Targeted Demand Management and the Employer of Last Resort Program}

The Employer of Last Resort (ELR) program is a New Deal type of program that provides government positions to anyone seeking work. Unlike private industries who compete over prices and wages, the ELR "industry" is not meant to compete with the private sector; rather it provides public services that are not offered by the private sector. The task here is to estimate the private sector effects of the implementation of the ELR program for the State of Missouri.

The economy is modeled in the traditional Keynesian sense, with the exception that employment, income, and output are disaggregated. This modeling approach is unlike the traditional Keynesian model found in the The General Theory and in textbooks alike. The traditional Keynesian model represents aggregate output, aggregate earnings, and aggregate employment by one variable. By separating out aggregate output, earnings, and employment, we can reflect the reality that Keynesian policies are not to "prime the pump" to close the recessionary gap, rather appropriate Keynesian policies rely on a targeted demand approach (Tcherneva, 2008). Earnings are expended on consumer goods across industries. Each industry's decision to expand employment in response to changes in final demand will be different and will be based upon the technical requirements of production specific to each industry.

Regional economic modeling of ELR programs creates the ability to identify the economic sectors that are affected by ELR employment, and to estimate the degree in which they are affected. It enables researchers to model the private sector benefits, specifically the additions to private sector output, earnings, and employment. Such an approach is applied here for the State of Missouri. For the analysis, data was collected from the Bureau of Economic Analysis (BEA) and Bureau of Labor Statistics (BLS). The most recent estimates available were used to perform the analysis.

\section{The Simple Theory of Economic Activity}

The forthcoming analysis will estimate the private sector economic impact after the implementation of an ELR program. To do this the analysis will rely on regional output, earnings, and employment multipliers for the State of Missouri. It is interesting to note that this type of analysis fits in neatly within a heterodox modeling of the economy, specifically the "Effective Demand Model" of Edward J. Nell (1998, 107-215, 1978, 2000). The Effective Demand Model (from here referred to as the Nell Model) is a variant of the traditional Keynesian model; the key difference is that the Keynesian model confounds aggregate income, aggregate output, and aggregate employment, whereas the Nell Model makes these variables explicit. Consistent with Keynes, the Nell Model describes an economy with 
persistent unemployment. It is not the interest of capitalists to maintain a fully employed economy. It is the interest of capitalists to maintain a "sufficient supply of available workers (Rose, 1995, 12)"

\subsection{Simple Economic Model}

The depiction of the economy can be described by the following structural relationships. Aggregate employment $(\mathrm{N})$ is dependent upon aggregate output $(\mathrm{Q})$, which corresponds to a predetermined level of final demand $\left(Y_{e}\right)$. Only in special circumstances will this level of output be consistent with full employment $\left(N_{f}\right)$. The level of employment is a function of the level of aggregate economic activity. The business enterprise makes investment, employment and output decisions dependent upon final demand. The pricing model is a mark-up over cost of production at a normal rate of output (Lee, 2010, 31). Pricing, output, and employment decisions are made to ensure the generation of cash flows required to meet profit expectations of those within the enterprise and among its shareholders; and to validate previous investment funded through external sources.

Aggregate consumption (C) will be a function of wage income (w) plus transfer payments by the Government in the form of unemployment insurance compensation made to those whose are officially unemployed (U). Weekly unemployment benefits vary state to state, but generally they replace on average 60 percent of the individual's average weekly pre-tax wage.

Investment spending (I) is equal to aggregate profits $(\pi)$ plus external financing $(\rho)$. This means that we would expect to find investment and profits to be highly correlated in the actual economy. This assumption is easily validated by the "Flow of Funds Accounts of the United States". Lastly, government spending is assumed to be autonomous $(\mathrm{G})$. The structural model of production displayed in the system of equations (Equation 1) is a slightly-modified "Nell Model" and is displayed graphically in Figure 1.

$$
\begin{aligned}
Y_{i t} & =\mathrm{C}_{i t}+I_{i t}+G_{t} \\
N_{i t} & =\mathrm{l}_{i} Q_{i t} \\
W_{t} & =\mathrm{wN}_{t} \\
C_{i t} & =0.40 \mathrm{wN}_{t}+0.60 w N_{F_{t}} \\
I_{i t} & =\pi_{i t}+\rho \\
G_{i t} & =\mathrm{G}_{t} \text { (note: Government Spending excludes transfer payments) }
\end{aligned}
$$

\subsection{Circular Production and the Nell Model}

The structural equations given for consumption investment, and government spending may easily be derived from NIPA (please refer to the Appendix) which disaggregated the economy into the final 
Figure 1: Nell's Effective Demand Model

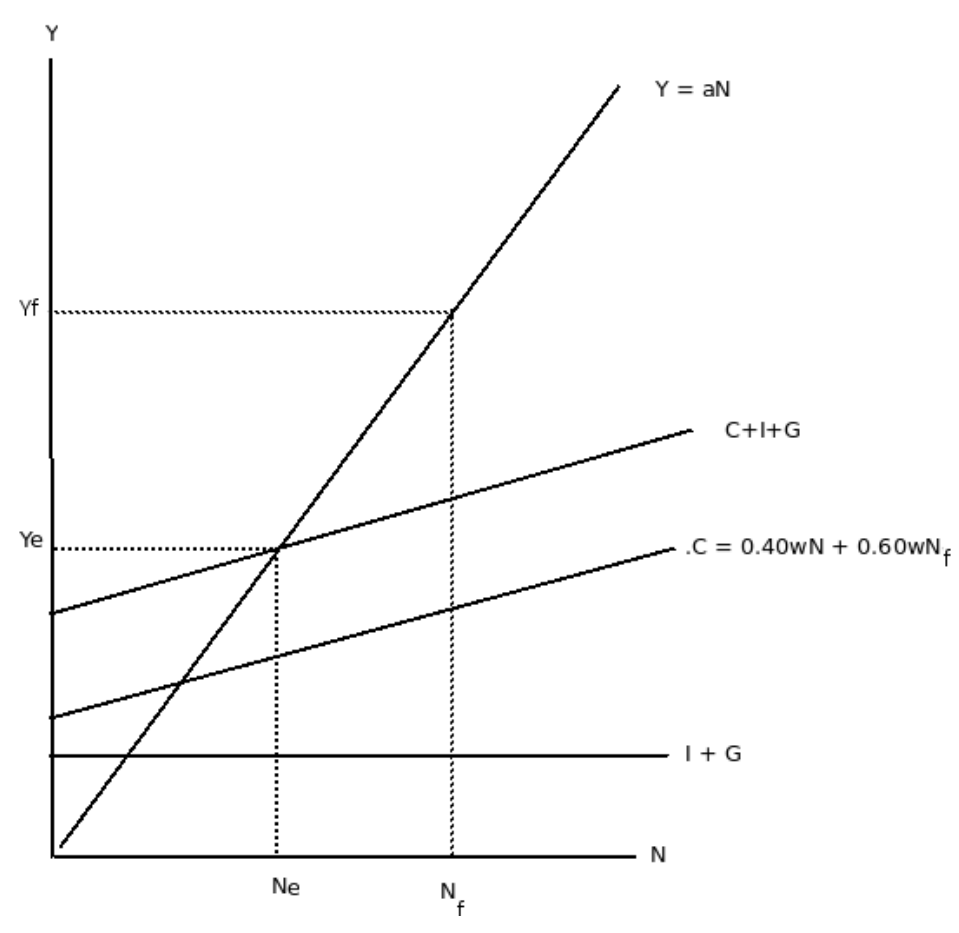

demand components and interindustry relationships displaying circular production as a social process. The balance between total equilibrium output $\left(\mathbf{Y}_{e}\right)$ and combined inputs (represented by the standard technology matrix $(\mathbf{A})$ ) can be generalized as:

$$
\mathbf{A} \times \mathbf{Q}+\mathbf{Y}_{e}=\mathbf{Q}
$$

Solving 2 for aggregate output at equilibrium $\mathbf{Y}_{e}$ yields:

$$
(\mathbf{I}-\mathbf{A}) \times \mathbf{Q}=\mathbf{Y}_{e}
$$

The equilibrium level of employment $\left(N_{e}\right)$ is given as:

$$
\mathbf{l} \times \mathbf{Q}=N_{e}
$$

\section{Application of the Nell Model for Regional Data}

Multipliers from the BEA are based upon the standard Leontief multiplier. The RIMS II dataset provides the user with final demand multipliers for output, earnings, and employment. The final demand multiplier for output indicates the change in output in each row industry that results in a $\$ 1.00$ change in final demand in the column industry. The multiplier for earnings is indicated by a 
$\$ 1.00$ change in earnings in each row industry that results from a $\$ 1.00$ change in final demand in the column industry. The final demand multiplier for employment indicates a $\$ 1.00$ million change in final demand in the column industry. The RIMS II multipliers are static, since they are based on static input output data. They therefore lack the appropriate time dimension. However since they are based on annual data, it is customary to assume that the economic impacts occur in one year (Ehrlich et al., 1997).

\subsection{Estimating the Impact of an Employer of Last Resort Program using Regional Data}

In order to estimate the regional impact of the ELR program on private sector income, output, and employment, the final demand multipliers must first be derived. Aggregate output is decomposed by sector corresponding to the "BEA 2002 Benchmark Input-Output Data." 1 The aggregate industries are given in Table 1.

Table 1: Economic Sectors

\begin{tabular}{ll}
\hline NAICS Code & Industry \\
\hline 11 & Agriculture, Forestry, Fishing and Hunting \\
21 & Mining, Quarrying, and Oil and Gas Extraction \\
22 & Utilities \\
23 & Construction \\
$31-33$ & Manufacturing \\
42 & Wholesale Trade \\
$44-45$ & Retail Trade \\
$48-49$ & Transportation and Warehousing \\
51 & Information \\
$52-53$ & Finance and Insurance and Real Estate and Rental and Leasing \\
54 & Professional and business services \\
$61-62$ & Educational services, health care, and social assistance \\
$71-72$ & Arts, entertainment, recreation, accommodation, and food services \\
81 & Other Services (except Government) \\
92 & Government \\
HH & Households \\
&
\end{tabular}

\footnotetext{
${ }^{1}$ URL: http://www.bea.gov/industry/io-benchmark.htm
} 


\subsection{Estimating Consumption Effects}

The effect additional income has on private sector industries depends upon the composition of consumption across industries. Additional consumption in any sector has multiplier effects due to interindustry linkages over all sectors of the economy. Unfortunately, Personal Consumption Expenditure (PCE) is unavailable at the state level so national PCE data serves as an adequate proxy for the state (refer to Appendix). National PCE is derived from the dataset "Use of Commodities by Industries; 2002 I-O Benchmark"(Use Table). Table 2 details the the commodities that are consumed by final users in dollars (replicated from the Appendix), and an additional calculated column detailing the consumption of commodities as a percentage of total consumption. 
Table 2: Use Table

\begin{tabular}{llcc}
\hline NAICS & 2002-Benchmark Industry & PCE (Dollars) & \% Total PCE \\
\hline & & & \\
11 & Agriculture, forestry, fishing and hunting & $\$ 48,655.1$ & 0.006457646 \\
21 & Mining & 118.3 & 0.0000157011 \\
22 & Utilities & $171,307.3$ & 0.022736403 \\
23 & Construction & 0.00 & 0.00 \\
$31-33$ & Manufacturing & $1,248,059.2$ & 0.165646045 \\
42 & Wholesale trade & $303,995.4$ & 0.040347153 \\
$44-45$ & Retail trade & $789,492.3$ & 0.104783713 \\
$48-49$ & Transportation and warehousing & $161,939.0$ & 0.021493015 \\
51 & Information & $311,503.2$ & 0.04134361 \\
$52-53$ & Finance, insurance, real estate, rental, and leasing & $1,845,786.9$ & 0.244978203 \\
$54-56$ & Professional and business services & $160,652.3$ & 0.02132224 \\
$61-62$ & Educational services, health care, and social assistance & $1,403,815.1$ & 0.186318421 \\
$71-72$ & Arts, entertainment, recreation, accommodation, and food services & $571,252.8$ & 0.075818332 \\
81 & Other services, except government & $401,797.6$ & 0.053327746 \\
92 & Government & $47,774.0$ & 0.006340704 \\
HH & Households & $68,345.9$ & 0.009071067 \\
\hline Summation & - & $\$ 7,534,494.4$ & 1.00 \\
\hline
\end{tabular}


Table 2 represents a proxy for PCE for each industry for the State of Missouri. The important column from Table 2 for the analysis to follow is the column "\% of Total PCE". This column is the percentage of total consumption spent on commodities in each industry. The column details the distribution of consumption by each industry from an additional dollar spent. This column will serve as weights for the regional multipliers

\subsection{Regional Multipliers}

The regional income, output, and employment multipliers are supplied from the BEA RIMS II dataset for the state of Missouri. Regional multipliers detail the amount of additional output, income, and employment that results from an increase in aggregate consumption for each industry. The regional final demand multipliers for the State of Missouri supplied by the BEA must first be weighted by the column "\% Total PCE" from Table 2 to derive a "weighted multiplier". The final demand multipliers are weighted as such to take into account the distribution of consumption expenditures across industries.

The weighted multipliers are then used to calculate the economic impact of additional consumption afforded by the implementation of an ELR program. The weighted output, income, and employment multipliers are given in Table 3. The "Weighted Output Multiplier" represents the addition to output for Industry $X$ resulting from a $\$ 1.00$ change in final demand for Industry $X$. The "Weighted Earnings Multiplier" represents the addition to earnings for Industry $X$ resulting form a $\$ 1.00$ change in final demand for Industry $X$. The "Weighted Employment Multiplier" represents the addition to employment for Industry $X$ resulting from a $\$ 1.0$ million change in final demand for Industry $X$ (Ehrlich et al., 1997, 2-5). 
Table 3: Weighted Multipliers

\begin{tabular}{|c|c|c|c|c|c|c|c|}
\hline NAICS & Industry & Output $(\$)$ & Earnings $(\$)$ & Employment (jobs) & PCE-Wght*Out & PCE-Wght*Earn & PCE-Wght*Empl. \\
\hline 11 & Agriculture & 2.14855625 & 0.41719375 & 16.4376125 & 0.013874616 & 0.00269409 & 0.106148288 \\
\hline 21 & Mining & 1.950863636 & 0.4148 & 16.21231875 & 0.0000306307 & 0.00000651282 & 0.000254552 \\
\hline 22 & Utilities & 1.6993 & 0.4163 & 15.625325 & 0.038635969 & 0.009465165 & 0.355263684 \\
\hline 23 & Construction & 2.317 & 0.3871125 & 14.2273625 & 0 & 0 & 0 \\
\hline $31-33$ & Manufacturing & 2.064902878 & 0.3943 & 13.545275 & 0.342042995 & 0.065314236 & 2.243721235 \\
\hline 42 & Wholesale Trade & 1.9288 & 0.39488125 & 12.90690625 & 0.077821589 & 0.015932334 & 0.520756924 \\
\hline $44-45$ & Retail Trade & 1.9899 & 0.4006125 & 12.5394625 & 0.208509111 & 0.041977665 & 1.313931442 \\
\hline $48-49$ & Trans. and Wrhsg & 2.111155556 & 0.4099375 & 12.328375 & 0.045375098 & 0.008810793 & 0.264973947 \\
\hline 51 & Info. & 1.980554545 & 0.4099 & 11.867425 & 0.081883275 & 0.016946746 & 0.490642194 \\
\hline $52-53$ & Finance, Insur. \& RE & 1.940430769 & 0.467846154 & 13.98557692 & 0.475363243 & 0.11461211 & 3.426161505 \\
\hline 54 & Professional services & 2.060504167 & 0.665875 & 19. & 0.043934565 & 0.014197947 & 0.416674244 \\
\hline $61-62$ & Educ. \& Hlth. & 2.162945455 & 0.714945455 & 27.74678182 & 0.402996582 & 0.133207508 & 5.169736578 \\
\hline $71-72$ & Arts and Entr. & 2.048483333 & 0.583408333 & 26.22474167 & 0.15531259 & 0.044233047 & 1.988316178 \\
\hline 81 & Other Services & 2.060975 & 0.46401875 & 10.9823375 & 0.10990715 & 0.024745074 & 0.585663299 \\
\hline 92 & Government & 2.17705 & 0.49589375 & 11.86860625 & 0.01380403 & 0.003144316 & 0.075255321 \\
\hline $\mathrm{HH}$ & Households & 1.4008 & 0.4927375 & 12.276525 & 0.01270675 & 0.004469655 & 0.111361175 \\
\hline
\end{tabular}


The weighted multipliers are displayed in the last three columns of Table 3. For an example of how to interpret Table 3, let aggregate income increase by $\$ 1,000,000$. This change in aggregate income would cause a subsequent increase in demand for commodities in all industries. Isolating just the impact this change has on agricultural products, output in the Agricultural Industry will increase by $(\$ 1,000,000 \times 0.013874616)$ or by $\$ 13,874.62$. The increase in earnings for the Agricultural Industry would rise by $(\$ 1,000,000 \times 0.00269409=\$ 2,694.09)$. The increase in Agricultural employment rises by $\left(\frac{\$ 1,000,000}{\$ 1,000,000} \times 0.11\right)$ which results in 0.11 additional jobs in the Agricultural Industry. These may not seem like meaningful results on the surface, but when we model the income effects from the ELR workforce as a whole, the private sector benefits become much more significant.

\section{Simulating the Impact of ELR for the State of Missouri}

The direct private sector economic impact from the creation of an ELR program for the State of Missouri can now be simulated. Assume that all eligible workers will enter into the ELR workforce. The best current estimate for this measure is the 2010 U-6 unemployment rate for the State of Missouri. The U-6 unemployment rate consists of those who are officially unemployed, plus discouraged workers, involuntary part-timers, and those who are marginally attached to the workforce, which is the broadest definition for the unemployment rate that the Bureau of Labor Statistics provides. In 2010 Missouri had 286,900 workers officially unemployed, 158,100 involuntary part timers, 39,800 workers unemployed due to lack of transportation or family responsibilities, and 20,400 discouraged workers. $^{2}$

To calculate the additional consumption from ELR employment some assumptions will be made:

\subsection{Assumptions for Simulations}

1. ELR income completely replaces unemployment compensation. All those who were previously eligible, received unemployment compensation.

2. Missouri ELR Workforce: Official Unemployed +.5 (involuntary part-timers) + Marginally Attached + Discouraged Workers

(a) Missouri 2010 ELR Workforce: 286, $900+.5(158,100)+39,800+20,400=426,150$ workers

3. 2010 Missouri ELR Wage: 2010 State of Missouri minimum wage $=\$ 7.25$

4. Work year: 2000 hours;

5. Payroll Deduction: Assuming the workers net income is 70 percent of their gross wages (After deduction of Federal, State, and Local taxes, FICA, Medicare, etc.).

\footnotetext{
${ }^{2}$ Source: "Measures of Labor Underutilization, Missouri - 2010" BLS Press Release July 7, 2011.
} 
(a) Individual ELR Worker's Annual Income: $.70(\$ 7.25 \times 2000 \mathrm{hr} / \mathrm{yr})=\$ 10,150.00 / \mathrm{yr}$

6. All ELR wage income is spent on consumption goods and savings out of ELR wages is zero.

The assumption now made is that a one dollar increase in income represents one dollar increase in final demand, to be divided among the given industries according to their weights given in the last three columns of Table 3. This effectively means that workers save nothing. However this assumption is not very unreasonable as each worker only receives $\$ 10,150$ in after-tax income annually from ELR employment. Workers in lower income brackets have lower marginal propensities to save, so the assumption that the ELR workforce spends their entire wages on consumption seems to be valid.

\subsection{Effects of ELR Income on the Private Sector}

Following the assumptions from the preceding section, we can now begin to analyze the economic impact of an ELR program for the State of Missouri in 2010. The first step in deriving the economic impact is to calculate the change in aggregate consumption after the implementation of the ELR program. It is assumed that ELR income replaces unemployment compensation, but not all the workers who entered into the ELR program were eligible for unemployment compensation; only the 286,900 workers who were officially unemployed were eligible. Assuming that unemployed insurance subsidies 60 percent of private-sector income, ELR employment would add an additional 40 percent of income equaling an additional $\$ 4060.00$ of after tax income. ${ }^{3}$

To calculate the additional income for the Missouri ELR workforce as a whole, we must divide the ELR workforce up into two groups, those who were officially unemployed and previously received benefits, and those who did not receive benefits prior to ELR employment. Those who were officially unemployed prior to joining the ELR will enjoy an additional $\$ 4060.00$ after tax income from ELR employment, and those who were not officially unemployed but still out of work, will enjoy an additional $\$ 10,150$ per year of after tax income from ELR employment. Total annual 2010 ELR income for the State of Missouri becomes:

$$
(286,000 \times \$ 4060)+(140,150 \times \$ 10,150)=\$ 2,583,682,500
$$

\footnotetext{
${ }^{3}$ This result is only valid if all those who received unemployment compensation previously held private sector employment paying the state minimum wage of $\$ 7.25 / \mathrm{hr}$. A more exhaustive study would need to analyze the exact unemployment compensation of all individuals making claims. In reality some individuals who collected unemployment insurance, and who made at or over $\$ 24,166$ annually from private sector employment, would be taking a monetary loss from accepting ELR employment at the state minimum wage rather than receiving unemployment compensation at 60 percent of their previous annual wage.
} 


\section{Additional Private Sector Stimulus from an ELR Program for the State of Missouri in 2010}

Equation 5 states that roughly an additional $\$ 2.58$ billion would be spent on ELR wages for the State of Missouri in 2010. This also means that private consumption expenditure will increase by $\$ 2.58$ billion. To calculate the affects this additional income has on private sector output and earnings, multiply the $\$ 2,583,682,500$ in additional income by the "Weighted Output Multipliers" and "Weighted Earnings Multiplier" given in Table 3 for each industry. Recall, the regional employment multipliers are for a $\$ 1.0$ million change. To calculate the effect that ELR income has on private sector employment, divide first $\$ 2,583,682,500$ by $\$ 1,000,000=\$ 2,583.6825$ then multiply this by the "Weighted Employment Multiplier" for all industries as given in Table 3.

The multiplier effects that an ELR program has on private sector output, earnings, and employment for all industries for the State of Missouri in 2010 are given below in Table 4 
Table 4: Additional Private Sector Stimulus from Consumption Spending out of ELR Income

\begin{tabular}{llll}
\hline Industry & Addition to Output & Addition to Earnings & Addition to Employment \\
\hline Agriculture & 35847603.46 & 6960672.366 & 2742.534736 \\
Mining, & 79140.11691 & 16827.07078 & 6.576804126 \\
Utilities & 99823077.94 & 24454979.9 & 9178.885632 \\
Construction & 0 & 0 & 0 \\
Manufacturing & 883730501.5 & 168751247.6 & 57970.6329 \\
Wholesale Trade & 201066278 & 41164093.31 & 13454.70551 \\
Retail Trade & 538721340.7 & 108456959.2 & 33947.81672 \\
Transportation and Warehousing & 117234845.9 & 22764291.1 & 6846.085496 \\
Information & 211560385.3 & 43785010.68 & 12676.6365 \\
Finance, Insur. \& RE & 1228187693 & 296121303.2 & 88521.13523 \\
Professional and business services & 113512966.6 & 36682986.55 & 10765.53953 \\
Educ. and Health & 1041215216 & 344165907.9 & 133569.5792 \\
Arts and Entertainment & 401278420.9 & 114284149.1 & 51371.77713 \\
Other Services & 283965180.9 & 63933414.18 & 15131.68018 \\
Government & 35665230.73 & 8123913.098 & 1944.35856 \\
Households & 32830207.61 & 11548168.49 & 2877.219192 \\
\hline TOTAL & $\mathbf{5 2 2 4 7 1 8 0 8 9}$ & $\mathbf{1 2 9 1 2 1 3 9 2 4}$ & $\mathbf{4 4 1 0 0 5 . 1 6 3 4}$ \\
\hline
\end{tabular}




\section{Summary of Results}

The implementation for the ELR program in the State of Missouri for 2010 would cost around $\$ 2.58$ billion of additional government spending in the form of ELR after tax wages. From Table 4 the multiplier effect for the State of Missouri would result in an additional $\$ 5,224,718,089$ of output and an additional $\$ 1,291,213,924$ in private sector earnings. Further, and most importantly, the results illustrate that the increase in consumer demand from ELR income would result in an additional 441,005 private sector jobs. This outcome effectively means that the ELR program could potentially result in near private sector full employment in the private sector for the estimated 505,200 who are either unemployed or involuntarily working part-time. This result is simply because the additional income provided by ELR employment must be spent in the private sector, which translates to more private sector output, private sector earnings, and private sector jobs.

These results also illustrate that there may be no better government policy to promote the creation of private sector jobs than for government to provide jobs, and additional disposable income, for all those willing and able to work. An effective method of achieving this is through the creation and implementation of an Employer of Last Resort Program. The ELR program will start off as a "big-government" program, but over the course of a year it will dwindle down. For the State of Missouri, it has been shown that if this program were implemented in 2010, the ELR program will start off costing roughly $\$ 2.5$ billion, but will be substantially less after the course of a year.

\section{Appendix}

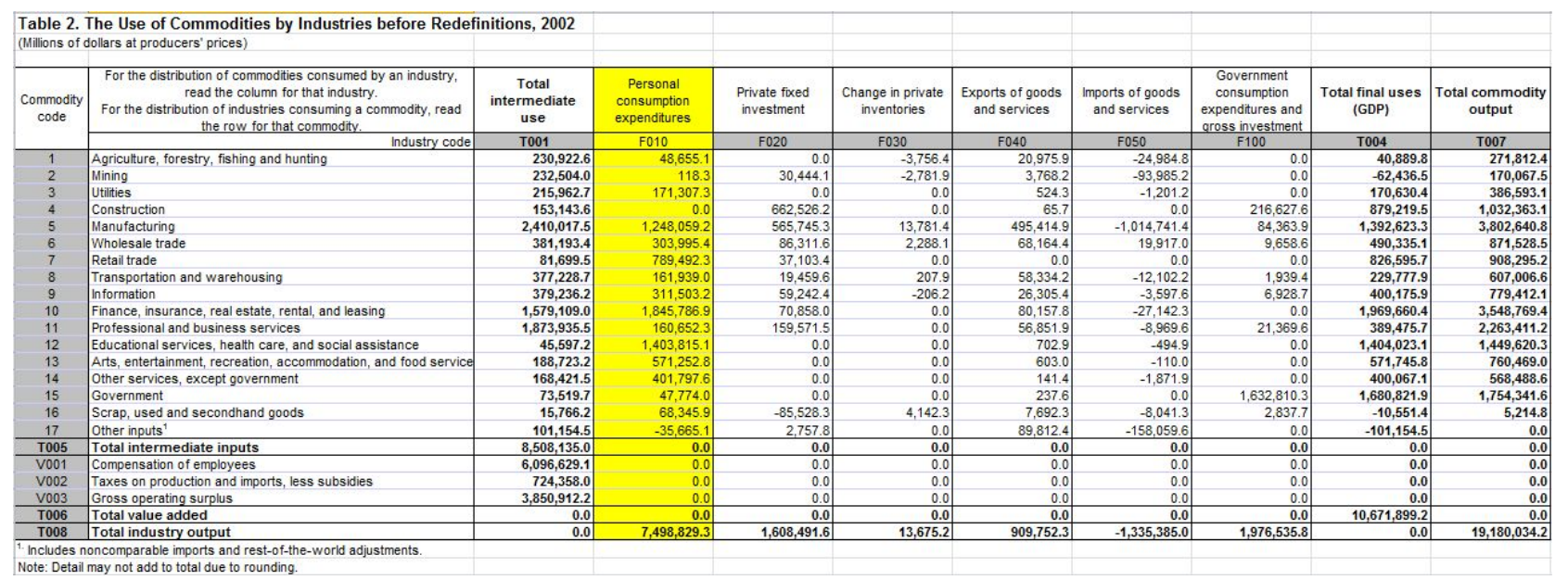




\section{References}

(2011, March). Federal reserve statistical release: Flow of funds accounts of the united states. Technical report, Board of Governors of the Federal Reserve System. http://www.federalreserve.gov/releases/z1/Current/z1.pdf.

Ehrlich, E. M., J. S. Landefeld, and B. L. Barker (1997, March). Regional Multipliers: A User Handbook for the Regional Input-Output Modeling System (RIMS II. U.S. Government Printing Office, Washington, DC 20402: BUREAU OF ECONOMIC ANALYSIS.

Lee, F. S. (2010). Alfred eichner's missing "complete model". In M. Lavoie, L.-P. Rochon, and M. Seccareccia (Eds.), Money and Macrodynamics: Alfred Eichner and Post Keynesian Economics, pp. 23-42. Armonk, NY: M.E. Sharpe.

Nell, E. (1978). The simple theory of effective demand. Intermountain Economic Review 9(2), 1-32.

Nell, E. (1998). The General Theory of Transformational Growth: Keynes after Sraffa. Cambridge: Cambridge University Press.

Nell, E. (2000). The simple theory of unemployment. In A. Warner, M. Forstater, and S. Rosen (Eds.), Commitment to Full Employment: The Economics and Social Policy of William S. Vickery, pp. 69-88. Armonk, NY: M.E. Sharpe.

Rose, N. (1995). Workfare or Fair Work: Women Welfare and Government Work Programs. New Brunswick, NJ: Rutgers University Press.

Tcherneva, P. (2008, August). Keyness approach to full employment: Aggregate or targeted demand? Working Paper 542, Jerome Levy Economics Institute of Bard College. 